\title{
Russia's Historical Role in the Intercultural Dialogue between Nations and Civilizations
}

\author{
Irina Ponizovkina \\ Department of History and Philosophy \\ Plekhanov Russian University of Economics \\ Moscow, Russia \\ irina-ponizovkin@mail.ru
}

\author{
Elena Agibalova \\ Department of Foreign Languages \\ Plekhanov Russian University of Economics \\ Moscow, Russia \\ elenagib@rambler.ru
}

\author{
Elena Gromova \\ Department of Finance and Prices \\ Plekhanov Russian University of Economics \\ Moscow, Russia \\ lengro@yandex.ru
}

\begin{abstract}
This article discusses the burning issue of Russia's special place in the intercultural space, which is presently subject to review on the global stage. It presents Russia's historical means of seeking a dialogue with other cultures and civilizations. The authors give special attention to the subject of Russia's mission, which has always loomed large in the spiritual aspect of the Russian state.
\end{abstract}

Keywords-Russia; Russia's mission; East-West; intercultural space; intercultural dialogue

\section{INTRODUCTION}

Russia, which geographically, economically, and spiritually has always been a bridge between the East and the West, has ample reason to claim a special historical role in the intercultural space. Currently however, Russia's traditional ambitions are not perceived so clearly by the world community. This is due to some countries' attempts to label Russia as 'a regional player' on the international stage. All these attempts (through 'Russia-bashing', political and economic sanctions, information wars, etc.) to prevent Russia's aspirations for integrating itself into such a habitual scheme as 'East-West' in the new conditions, have already resulted in world imbalance and the aggravation of contradictions. Therefore, it may be suggested that such a policy against Russia, leading to disharmonizing international relations stretching back over centuries, will ultimately be doomed to failure.

Russia's interior spiritual life initially stood in close interrelation and interdependence with the relations with the diversified surrounding world of other cultures, countries and nations. However, this in no way meant the absence of its own culture. On the contrary, it was evidence of its passionate interest in other 'civilizations' and desire to enter into a cross-fertilizing cultural dialogue with them. Even the traditional question of Russia's mission and spiritual search has always been surprisingly concerned with its proclivity for a dialogue with other countries and cultures, as well as with the formation of multicultural space.

\section{THE QUESTION OF RUSSIA`S MISSION IN THE INTERCULTURAL DiALOGUE}

One of the first, still tentative attempts for selfidentification and taking interest in the Russian people's destiny was made in the ancient times by Nestor the Chronicler and expressed in his questions as "Where is the land of Russia originated from?" This matter was even more deeply embodied in Metropolitan Hilarion in his "Sermon on Law and Grace" in the 11th century. This work is dedicated to the concept of the choice of faith by the Russian people as an important fact that identifies Russia's historical development and role among other lands. Having chosen Christianity, Russia not only gained a special spiritual inner strength, but also became a state influencing the destiny of human history. It ranked among other states, became equal to them by Divine Grace and, therefore, began holding a dialogue with them as equals. Describing his doctrine of all nations' equality, Hilarion emphasizes repeatedly that Russia is a part of mankind which, with its introduction to Christianity, acquired voting rights in the cultural interchange. "The blessed faith has spread across the earth to come to our land of Russians... ... The gospel spring has filled in and covered all earth to spread out up to us, too. Hence, we, together with all Christians, confess the Holy Trinity" [1].

Until the 18th century, the existential question of Russia's mission was in religious form, which was typical of the medieval way of thinking. Such an idea as 'missionism' especially appeared in the 15 th and 16 th centuries. The 'Moscow is the Third Rome' spiritual and political doctrine outlined by an elder of the Pskov Monastery, Philotheus, substantiated the world-wide historical significance of the capital of the Russian state as the ecclesiopolitical center. 
The idea of Moscow as 'the Third Rome' was anticipated by the earlier development of political thought in Russia, the final emancipation from the Tartar Mongol Yoke, the national self-identification process, the political and military situation, and the acceptance of the Russian state independence. Moscow must be the successor of both Roman and Byzantine Empires which had fallen, in Philotheus' opinion, due to the loss of faith. A researcher, N. Sinitsyna, Doctor of Historical Sciences and the author of such monographs as "The Third Rome: the Russian Medieval Concept Origins and Evolution", speaks of that in her interview as, "It stands to reason that 'the Third Rome' is not only Moscow, and even is as much a state than Moscow the function of which is to serve as the guarantor of the long terrestrial history of mankind. This function comes up not as a pretention, but as a result of the certain historical case, the naturally prevailing conditions: the loss of political independence by all orthodox Slavic and Balkan kingdoms, the downfall of the Byzantine Empire, the 'secession' of the First ('great') Rome" [2]. Thus, Russia was provided with the role of the guardian of faith. The Orthodoxy was becoming 'Russian' and that development was what defined the Russian state's global role.

Many Russian researchers (Y. Lotman, M. Bibikov, and others) believe that the Russian-Byzantine dialogue in general (like the Russian-Balkan one), being one of the originators of the Russian culture, is not merely an episode essential for studying the bygone days, but a long-acting structural factor in the history of Russian culture [3]. Modern political history confirms this fact. Y. Lotman believes that, for the millennium between the 10th and 20th centuries, Russian culture experienced a state of 'the historical collision of the dialogue of cultures': they were the Russian-Byzantine dialogue originated by 'the Christianization' of Russia, and the 'East-West' dialogue begun by Peter the Great [4].

\section{THE FORMATION OF THE 'RUSSIAN IDEA' AND THE NATIONAL IDENTITY}

In the 19th century, after the heroic Patriotic War of 1812-1814, the Russian army's foreign campaigns in Germany and France, and the Decembrist Revolt, the question of Russia's mission became more compelling, but with a new focus. The question of religion became minor, though it still persisted. The problem of the relations with the West assumed a life-changing character. A thinker, Chaadayev, brought 'the great schism' to the history of the Russian identity: conflict between the advocates of the West and the adherents of 'his own' way. New antithetical streams of Russian social thought were formed: Occidentalism (or Westernism) and Slavophilism. However, on closer inspection, 'extremes meet'. The writer and philosopher, N. Chernyshevsky, wrote, "We are meant to renew the civilized world's life, bringing those superior elements to it which it is unable to produce by itself. Take a good look at a most avowed Westernist - he will often be a Slavophil on this side" [5]. Many Slavophils (Kireyevsky, Khomyakov, and others) came to their understanding of the place of 'Holy Russia' through a deep, even admiring, dialogue with the West.
The development of the philosophical views of the Russian thinker and writer A. Hertsen is especially illustrative in this respect. At first, he was a diehard Westernist. However, after visiting Europe and staying there for some time, he was quite disappointed with it. "Europe is sinking to the bottom because it cannot get rid of its load with an abyss of pillage from a distant and dangerous cruise". His belief in Russia and its future saved him from moral death. "I feel it with my heart and mind, - he wrote, - that history is thrusting at our (Russian) door". [6]. Hertsen became the founding figure in a new public movement in Russia, Peasant Socialism (or Populism). His primary goal was to find a path for Russia which would have allowed for emancipating it from the shameful serfdom and, at the same time, avoiding the Western narrow-minded capitalism. Finally, he proposed this means: through the Russian community. He came to the conclusion that Russia is able to develop in its own way, with no need for imitating others.

\section{THE SIGNIFICANCE OF THE IDEA OF UNITOTALITY IN THE RUSSIAN PHILOSOPHY}

F. Dostoyevsky, along with L. Tolstoy, became the symbol of Russian identity. Having analyzed the specific features of Western and Russian history, economy, and culture, he came to the following conclusion: "We believe that the Russian nation is a phenomenon in the history of all of mankind". However, the Russian feeling of having been chosen neither grants any privileges to Russia, nor sets it apart. For its only unique feature is to become all people's brother and enter into a dialogue with the world. "Indeed, the role of Russians is unquestionably Europe-wide and worldwide. To become a real Russian, totally Russian, maybe, just means to... be a brother of all people, all-human, if you like... To a real Russian, Europe and the lot of the whole Aryan race are as precious as the lot of our land, for it is universality, which is our lot, earned not by the sword, but by the power of our fraternity and fraternal aspiration towards the people reunification... For the worldwide fraternal unification, common to all mankind, the Russian soul among all nations is, maybe, most appropriate... And I can see the traces of all of this in our history..." [7]

This idea of the Russian 'unitotality' in the Russian psyche first noted by Dostoyevsky was then taken up and developed by V. Solovyov in the late 19th and early 20th centuries. He deserves credit for developing and taking the problem to a new level, since then called 'the Russian idea'. Some believe that the concept of 'the Russian idea' was first used by Solovyov in his self-titled article in 1888. In the philosopher's opinion, "every nation is meant to carry out a certain mission. Otherwise, the nation's existence is undue. The national idea is the people's duty ordained by God. The national idea is not what the nation thinks of itself through time, but what God think of it through eternity" [8]. At the same time, this is a contribution that every nation is meant to make to the development of human achievements. The more the national mission helps to achieve the unity common to all mankind, the higher is its significance. Thus, in V. Solovyov's understanding, 'the Russian idea' is Russia's mission for mankind. Moreover, he understands it in an 
ambivalent manner. First, Russia's duty is to become the backbone of the spiritual unification of Christendom. Second, by its geographical and political position, Russia is in the middle of the East and the West, and this abets its higher purpose. Thinking of Russia's fate and fortunes to come, V. Solovyov wrote that "Russia's future word is the word of reconciliation between the East and the West, spoken in league with God" [9], since Russia is free from such disadvantages and extremes inherent with them as the excessive despotism of the East and the excessive individualism of the West.

Similarly, the philosopher Berdyayev wrote in 1918, “...By cruel sacrifice and suffering, the world is coming up for solving the problem of worldwide historical significance - the problem of the East and the West, and the core role here will fall to Russia's lot" [10]. Another philosopher, I. Iljin, had a keen eye for the distinctive character of the Russian state and the unique Russian experience concerning international coexistence. "None of the nations has ever had such burden and such mission as Russians... Not to exterminate, not to suppress, not to enslave any flesh and blood; not to strangle any foreign life; but to give birth and breath to everyone; to reconcile everyone, to let everyone pray in their own way, work in their own way and to involve the best from everywhere in the state- and cultural building" [11].

This idea has become an expression of self-sentiment of the Russian psyche; it is used in dialogues with the surrounding cultures and nationalities. The state national policy of the Soviet era strengthened such self-sentiment to some extent, making the Russian culture (the Russian language, etc.) a linchpin, around which international relations were built.

Among the public figures in Russia during the 20th century, D. Likhachev distinguished himself with his reverential and concerned attitude about the question of Russia's mission. He raised the issue of the historical and cultural continuity of generations. There is no future without the past; those who do not know the past cannot foresee the future. He considered it especially relevant to Russia - a country with a centuries-old proud history, the wealth of its culture, and historical traditions. None of this should be lost; this is Russia's strong point and it can give much to the world. Furthermore, Likhachev saw a special value in the long-standing dialogue with other cultures. "So, the place of Russian culture is defined by its diversified ties with the cultures of a great many nations of the East and the West. These ties could be talked and written about with no end in sight. And whatever the tragic severance in such ties, whatever their abuse, all in all, it is ties, which are the most valuable thing in the position held by Russian culture (definitely culture, not the lack of it) in the surrounding world" [12].

\section{CONCLUSION}

S. Huntington noted that, from the late 20th to the early 21 st century, economic and other differences gave place to the cultural distinctions, "where the focus is to a lesser extent on the differences in economic welfare and to a greater extent - on the differences in the fundamental philosophy, values and way of life" [13]. Thus, the theory of multiculturalism appears (C. Taylor, A. MacIntyre, and others) along with such accompanying concepts as 'westernization', 'creolization', etc., to consider the cultural differences [14][15][16]. In the age of globalization and allembracing migration processes, multiculturalism has become a special policy of the Western governments: promotion of the ever-increasing and ever more visible cultural diversity, forms of autonomy, and self-reliance of cultures [17]. However, those European countries embarking on this course have recently been bound to acknowledge the failed character of such a policy, which did not find the expected success and consent, even with the ideological support of the widespread concept of tolerance [18]. The expected conflictfree coexistence of the numerous supported diversified cultural communities in the same social setting has failed. President V. Putin has described this process as, "Those most developed and wealthiest countries so proud of their tolerance before, have met face to face with 'the aggravation of the issue of inter-ethnic relations'. And today they, one by one, are announcing the failure of the attempts to integrate the foreign cultural element into society and provide a conflict-free, well-balanced interaction between different cultures, religions and ethnic groups" [19].

Subsequently, Russia, with its state experience of the centuries-old coexistence of different cultures and ethnic groups, could have its influence on that issue. However, in the post-Soviet Russia, there were no clear national policy principles worked out to take its historical experience and the geopolitical achievements of the past generations into account. This issue of the intercultural dialogue is currently of prime importance to Russia, since it directly affects all mainstream areas of the country and its position on the global stage [20]. "To Russia - with its diversity of languages, traditions, ethnic groups and cultures - the issue of inter-ethnic relations is fundamental, without exaggeration. Any responsible politician or public figure must realize that one of the fundamental terms of our country's existence itself is the civil and international consent" [21]. The traditional mission of Russia and its historical experience in building an intercultural dialogue based on the universal values, common activities, and mutual obligations are still relevant. They are greatly needed by the international community, which is facing new global cross-cultural challenges.

\section{REFERENCES}

[1] Hilarion, Sermon on Law and Grace // http://azbyka.ru/dictionary/02/ilarion_slovo_o_zakone_i_blagodatiall.shtml (Reference date: 1 November 2016).

[2] The Third Rome - a Story of Some Idea // http://www.domprio.ru/moscowrim (Reference date: 1 November 2016).

[3] M. Bibikov, Russia and Byzantine Empire: a Meeting of Two Cultures, Russia between the East and the West: Culture and Society, 10th-17th Centuries, Chapter 3, Moscow, 1991, p. 214. 
[4] Y. Lotman, The Issues of the Byzantine Empire's Impact on Russian Culture in the Typological Interpretation, Byzantine Empire and Russia, Moscow, 1989, pp. 227-236.

[5] N. Chernyshevsky, Of the Downfall of Rome, Complete works in 16 volumes, vol. VIII, Moscow: GOSLITIZDAT, 1939-1953, pp. 171.

[6] A. Herzen, Russians and Socialism, in 2 volumes, Moscow: MYSLJ, 1986, vol. 2, pp. 154-155.

[7] F. Dostoyevsky, Diary of a Writer, complete works, vol. IX, X, XI, Moscow, 1906.

[8] Solovyov, The Russian Idea, Russia through the Eyes of Russians, Saint-Petersburg: Nauka, 1991.

[9] Cit. Ex: V. Shubart, Europe and the East Soul, Moscow, 2000, p. 29.

[10] N. Berdyayev, Russia's Fortunes, 1918. http://predanie.ru/berdyaev-nikolay-aleksandrovich/book/69716sudba-rossii (Reference date: 1 September 2017).

[11] I. Iljin, Of Russia, collected works in 10 volumes: vol. 6, book II, Moscow, 1996, pp. 20-21.

[12] D. Likhachev, Thinking of Russia, Nauka I Zhizn, 2007, No 1.

[13] S. Huntington, Collision of Civilizations, Moscow, 2007, pp. 30.

[14] O. V. Chistyakova, Relationship of Self and Other in Cultural and Religious Communicatons, Proceedings of the 2016 3rd International Conference on Education, Language, Art and Inter-cultural Communication (ICELAIC 2016) Advances in Social Science, Education and Humanities Research, Xiamen, 2017, pp. 660-664.

[15] O.V. Chistyakova, Self and Other in the Communicative Space of the Global World, the Proceedings of the 2017 2rd International Conference on Contemporary Education, Social Sciences and Humanities, 2017, pp. 6-11.

[16] O. Chistyakova, The "Other" Culture Formation in Russia. The View Through the Informational Society Theory and Actual Process of External Migration, the Proceedings of the 2016 3rd International Conference on Education, Language, Art and Inter-cultural Communication (ICELAIC 2016) Advances in Social Science, Education and Humanities Research. Xiamen, 2017, pp. 626-631.

[17] I. F. Ponizovkin, Where Modern Philosophy is Going: Results of the 23-rd Global Philosophy Congress in Athenes (Greece), The Plekhanov Russian University of economics Press, 2014, No. 6 (72), pp. 154-158.

[18] O. Chistyakova, Postmodernism, Christian Patristics, and Values of Peace in the Modern Cultures. (In the Context of Educational Process), the Proceedings of the 2016 International Conference on Arts, Design and Contemporary Education, 2016, pp. 994-999.

[19] V. Putin, "Russia: The Issue of Inter-Ethnic Relations" // www.NEWSru.com.

[20] I.F. Ponizovkina, Modern Intercultural Space and Problems of Ecophilosophy, the Proceedings of the 2016 3rd International Conference on Education, Language, Art and Inter-cultural Communication (ICELAIC 2016) Advances in Social Science, Education and Humanities Research, Xiamen, 2017, pp. 639-642.

[21] V. Putin, Russia: The Issue of Inter-Ethnic Relations // www.NEWSru.com. 